No.159

First Price Package Auction with Many Traders

Yasuhiro Shirata

June 2013

Department of Economics

Otaru University of Commerce 



\section{First Price Package Auction with Many Traders *}

\section{Yasuhiro Shirata ${ }^{\dagger}$}

June 5, 2013

We study a first price package auction with many buyers and many sellers in a decentralized networked market. We show that any equilibrium with profit-target strategies is efficient and the set of the equilibrium payoffs is equal to a bidder optimal core relative to an exogenously given network. We further show that in the bidder optimal core, each buyer earns a less payoff than the VCG payoff, but does a larger payoff than the competitive equilibrium payoff. Finally, we discuss coalition-proofness and stability of networks.

\section{Introduction}

A package auction is a selling mechanism where each buyer bids on bundles of multiple items, or packages. The theory of the package auction recently plays an important role in the real economy. For example, the U.S. and the U.K. governments sell their bundles of spectrum bands under the guidance of auction theorists (see e.g. Cramton et al. (2006)).

In their seminal paper, Bernheim and Whinston (1986) first analyze a static package auction in which only one seller exists. They show that there exist equilibria where each bidder is truth-telling, and the corresponding equilibrium payoffs are in the bidder-optimal frontier of the core. Ausubel and Milgrom (2002) show that the bidder-optimal frontier of the core is implemented by their dynamic ascending proxy package auction with a single seller. This paper extends the static first price package auction model with a single seller to that with multiple sellers, and show that the results of Bernheim and Whinston (1986) hold true in the auction with multiple sellers.

\footnotetext{
"I am very grateful to Professor Akira Okada for his guidance and encouragement. I also thank seminar participants at Kobe university, GTW2011, Kyoto university, CTWE, SING8, and GAMES2012.

$\dagger^{\dagger}$ Department of Economics, Otaru University of Commerce, 3-5-21 Midori, Otaru, Hokkaido, 047-8501, Japan.

E-mail: yasuhiro.shirata@gmail.com
} 
Furthermore, this paper studies an auction market where a network structure is embedded. We often observe that a large two-sided market with many traders is networked. Each trader cannot encounter any other trader unless they are linked. Kranton and Minehart (2001) and CorominasBosch (2004) characterize a relation to the competitive equilibrium in networked markets using centralized mechanisms.

A natural class of selling mechanisms between multiple buyers and multiple sellers is the class of centralized mechanisms. Each centralized mechanism (e.g. the Vickrey-Clark-Groves (VCG) mechanism and the Double auction) assumes the existence of a unique auctioneer or a unique market maker who can collect all messages from all buyers and all sellers, compute an array of trades and prices, and impose them. If the market maker exists, the VCG mechanism implements an efficient allocation and the Double auction mechanism implements the competitive equilibrium, respectively.

In contrast, this paper assumes no market maker. We study a class of decentralized mechanisms, where each buyer's message is a collection of separate messages sent to different sellers-one for each seller, and all actions of a particular seller and her final allocation is independent of messages that the buyers send to other sellers (Peters and Severinov (2006)). Our motivations are as follows. First, implementing the centralized VCG mechanism would be difficult because of computational complexity in a large market consisting of multi-buyers and multi-sellers. Second, many real exchange markets (e.g. a wholesaler-retailer market and a manufacturer-supplier market) have no market maker. Third, emergence of market makers is often prohibited by the government from the view of antitrust law.

Peters and Severinov (2006) analyze a decentralized auction with many sellers where buyers have single-unit demands and sellers have single-unit supplies. They show that the existence of a symmetric perfect Bayesian equilibrium resulting in the Vickrey outcome. Anwar et al. (2006) support their prediction by testing data from competing auctions in eBay.

In an auction with multi-object demand and multi-object supply, we show that there exist equilibria where each buyer bids truthfully given a network, and any corresponding equilibrium payoff vector is efficient and in a bidder optimal core relative to a given network. This result is an extension of Milgrom (2004, Theorem 8.7). He further shows that in the auction with a single seller, the equilibrium outcome is unique and equal to the VCG outcome if goods are substitutes for all buyers. 
In our auction with multiple sellers, in contrast, we find that in any equilibrium, each buyer earns less payoff than his/her VCG payoff and greater payoff than his/her competitive equilibrium payoff.

The rest of the paper is organized as follows. Section 2 introduces a networked market with many buyers and many sellers, and models a first price package auction. Section 3 provides our main results. We show that the set of equilibrium payoffs is the same as the bidder-optimal core relative to an exogenously given network. Sections 4 investigate relations to the VCG mechanisms and the competitive equilibrium. Section 5 discusses coalition-proofness of equilibria and stability of networks, and Section 6 concludes.

\section{Preliminaries}

\subsection{A Pure Exchange Networked Market}

A (pure exchange) networked market consists of $b$ buyers indexed by $i=1, \ldots, b$ and $s$ sellers indexed by $j=1, \ldots, s$. Let $I$ and $J$ be the set of buyers and the set of sellers, respectively. They trade $N$ commodities indexed by $n=1, \ldots, N$. Each commodity $n$ is perfectly divisible. We denote each package or bundle of commodities by $x \in \mathbb{R}_{+}^{N}$ and the set of all bundles by $X$.

Each seller $j$ has endowments $\omega_{j} \in \mathbb{R}_{+}^{N}$ and a valuation function $v_{j}$ over $X$. Each buyer $i$ has no endowments and a valuation function $v^{i}$ over $X$. Valuation functions $v^{i}$ and $v_{j}$ satisfy continuity, quasi-concavity, and free disposal, i.e. $v^{i}(x) \geq v^{i}\left(x^{\prime}\right)$, and $v_{j}(x) \geq v_{j}\left(x^{\prime}\right)$ for all $x, x^{\prime} \in X$ with $x \geq x^{\prime}$. For normalization, let $v^{i}(0)=v_{j}(0)=0$. We assume that $v^{i}, v_{j}$, and $\omega_{j}$ are common knowledge among all buyer $i$ and all seller $j$ (Complete information).

The market is networked. Let $i j$ be a link between buyer $i$ and seller $j .{ }^{1}$ A set of links $g \subset\{i j\}_{i \in I, j \in J}$ is a (bipartite) network in the networked market. All trading between buyers and sellers are restricted by network $g \subset\{i j\}_{i \in I, j \in J}$. Each pair of buyer $i$ and seller $j$ can trade if and only if they are linked, i.e. $i j \in g$. Let $L^{i}(g)$ be the set of sellers who are linked to $i$, and $L_{j}(g)$ be the set of buyers who are connected to $j$. We denote an allocation from seller $j$ to buyer $i$ by $x_{j}^{i}=\left(x_{j 1}^{i}, \ldots, x_{j N}^{i}\right)$. For simplicity, we denote an allocation to $j$-self by $x_{j}^{0}=\omega_{j}-\sum_{i} x_{j}^{i}{ }^{2}$

\footnotetext{
${ }^{1}$ In what follows, the left $i$ designates a buyer and the right $j$ designates a seller.

${ }^{2}$ In what follows, the superscript $i$ designates buyer $i$ and the subscript $j$ designates seller $j$.
} 
Definition 1. An allocation $x=\left(x_{1}^{1}, x_{2}^{1}, \ldots, x_{s}^{b}\right) \in \mathbb{R}_{+}^{b \times s \times N}$ is feasible relative to network $g$ ( $g$-feasible) if

$$
\begin{aligned}
\sum_{j} \omega_{j} & \geq \sum_{i, j} x_{j^{\prime}}^{i} \\
x_{j}^{i} & \geq 0 \text { for all } i j \in g, \text { and } \\
x_{j}^{i} & =0 \text { for all } i j \notin g .
\end{aligned}
$$

Let $F(g)$ be the set of $g$-feasible allocations.

We assume that all buyers and all sellers have quasi-linear payoff functions. A Pareto-efficient allocation relative to $g$ is defined as follows:

Definition 2. An allocation $\bar{x}(g)=\left(\bar{x}_{1}^{1}(g), \ldots, \bar{x}_{s}^{b}(g)\right)$ in the networked market $g$ is $g$-efficient if

$$
\bar{x}(g) \in \arg \max _{x \in F(g)} \sum_{i} v^{i}\left(\sum_{j} x_{j}^{i}\right)+\sum_{j} v_{j}\left(x_{j}^{0}\right)
$$

\subsection{First price package auction in a networked market}

We develop a decentralized mechanism in which each seller $j$ sells $j$ 's endowments using a first price package auction. A first price package auction is organized as follows:

Step 1. Each buyer $i$ bids a payment schedule $t_{j}^{i}\left(x_{j}^{i}\right)$ for $j \in J$ simultaneously, where $x_{j}^{i}=\left(x_{j 1}^{i}, \ldots, x_{j N}^{i}\right)$ is an allocation from $j$ to $i$. We assume $x_{j}^{i} \geq 0$ and $t_{j}^{i}\left(x_{j}^{i}\right) \geq 0$ for all $i, j$, and $x_{j}^{i}$. For seller $j \notin L^{i}(g)$ who does not linked with $i, t_{j}^{i}\left(x_{j}^{i}\right)=\varnothing$.

Step 2. Each seller $j$ allocates commodities $x_{j}=\left(x_{j}^{1}, \ldots, x_{j}^{b}\right) \in \mathbb{R}_{+}^{b \times N}$, simultaneously. For buyer $i \notin L_{j}(g)$ who does not linked with $j, x_{j}^{i}=(0, \ldots, 0) \in \mathbb{R}_{+}^{N}$. By the resource constraint, an allocation to $j$-self $x_{j}^{0}=\omega_{j}-\sum_{i} x_{j}^{i} \geq 0$.

In Step 1, each buyer $i$ offers a payment schedule $t_{j}^{i}\left(x_{j}^{i}\right)$ to any linked seller $j \in L^{i}(g)$. Each payment schedule $t_{j}^{i}$ depends only on an allocation from $j$ to $i, x_{j}^{i}$, and cannot depend on other $x_{l}^{k}(k l \neq i j)$. After bidding, each seller $j$ allocates commodities to buyers $x_{j}=\left(x_{j}^{0}, x_{j}^{1}, \ldots, x_{j}^{b}\right)$ in Step 2. Finally, each buyer $i$ pays sellers for $x^{i}=\left(x_{1}^{i}, \ldots, x_{s}^{i}\right)$, according to the given $i$ 's bids $t^{i}=\left(t_{1}^{i}, \ldots, t_{s}^{i}\right)$. 
Let $t=\left(t^{1}, \ldots, t^{b}\right)$ be a strategy profile of buyers, and $x=\left(x_{1}, \ldots, x_{s}\right)$ be an allocation profile of sellers. The payoff functions for buyer $i$ and seller $j$ over a profile $(t, x)$ are given by

$$
\begin{aligned}
& \Pi^{i}(t, x)=v^{i}\left(\sum_{j \in L^{i}(g)} x_{j}^{i}\right)-\sum_{j \in L^{i}(g)} t_{j}^{i}\left(x_{j}^{i}\right) \\
& \Pi_{j}(t, x)=v_{j}\left(x_{j}^{0}\right)+\sum_{i \in L_{j}(g)} t_{j}^{i}\left(x_{j}^{i}\right) .
\end{aligned}
$$

\subsection{Profit-Target Strategies}

Let $t_{j}=\left(t_{j}^{1}, \ldots, t_{j}^{b}\right)$ be a bidding profile to $j$. Given $t_{j}$, independently of a bidding profile to other sellers $t_{-j}$, seller $j$ maximizes the payoff function $\Pi_{j}(t, x)$. Let $X_{j}^{*}\left(t_{j}\right)=\arg \max _{x_{j}} \Pi_{j}(t, x)$. Each seller $j$ chooses $x_{j}^{*}\left(t_{j}\right) \in X_{j}^{*}\left(t_{j}\right)$ for any $t_{j}$. Fix a profile $\left(x_{j}^{*}\left(t_{j}\right)\right)_{j \in J}$ for each bidding profile $t$. Then, the auction is truncated to normal form game $\Gamma=\left(t^{i}, \Pi^{i}\right)_{i \in I}$, where a payoff function for buyer $i$ is redefined by

$$
\Pi^{i}(t)=v^{i}\left(\sum_{j} x_{j}^{i *}\left(t_{j}\right)\right)-\sum_{j \in L^{i}(g)} t_{j}^{i}\left(x_{j}^{i *}\left(t_{j}\right)\right)
$$

Definition 3. Let $\pi^{i}=\left(\pi_{1}^{i}, \ldots, \pi_{s}^{i}\right)$. For any profile $t$, buyer $i$ 's bidding strategy $t^{i}=\left(t_{j}^{i}\right)_{j \in J}$ is a $\pi^{i}$-profittarget strategy if for all $t_{j}^{i}$, all $x_{j}^{i}$, and $j \in L^{i}(g)$,

$$
t_{j}^{i}\left(x_{j}^{i}\right)=\max \left\{0, f_{j}^{i}\left(x_{j}^{i}\right)-\pi_{j}^{i}\right\},
$$

where

$$
f_{j}^{i}\left(x_{j}^{i}\right)=v^{i}\left(x_{j}^{i}+\sum_{l<j} x_{l}^{i *}\left(t_{l}\right)\right)-v^{i}\left(\sum_{l<j} x_{l}^{i *}\left(t_{l}\right)\right) .
$$

Note that $\sum_{j \in J} f_{j}^{i}\left(x_{j}^{i *}\left(t_{j}\right)\right)=v^{i}\left(\sum_{j \in J} x_{j}^{i *}\left(t_{j}\right)\right)$. This implies that any $\pi^{i}$-profit-target strategy reveals $i$ 's valuation function truthfully. Given $i$ 's allocation $\left(x_{l}^{i *}\left(t_{l}\right)\right)_{l<j}$ from sellers $l<j$, buyer $i$ 's payment schedule to seller $j$ is a function defined as the increase of true valuation minus constant target profit $\pi_{j}^{i}$ for any package $x_{j}^{i}$ and any seller $j$. Each buyer $i$ earns the sum of target profit $\sum_{j \in J} \pi_{j}^{i}$.

Proposition 1. For a bidding profile of other buyers $t^{-i}$, take a best response $t^{i} \in \arg \max _{t^{i}} \Pi^{i}\left(t^{i}, t^{-i}\right)$. 
Let for $j \in J$,

$$
\begin{aligned}
\bar{\pi}_{j}^{i} & =v^{i}\left(x_{j}^{i *}\left(t_{j}\right)+\sum_{l<j} x_{l}^{i *}\left(t_{j}\right)\right)-v^{i}\left(\sum_{l<j} x_{l}^{i *}\left(t_{j}\right)\right)-t_{j}^{i}\left(x_{j}^{i *}\left(t_{j}\right)\right) \\
f_{j}^{i}\left(x_{j}^{i}\right) & =v^{i}\left(x_{j}^{i}+\sum_{l<j} x_{l}^{i *}\left(t_{j}\right)\right)-v^{i}\left(\sum_{l<j} x_{l}^{i *}\left(t_{j}\right)\right) .
\end{aligned}
$$

Then, the $\bar{\pi}^{i}$-profit-target strategy is a best response of buyer $i$ to $t^{-i}$.

Proof. Since $\sum_{j} \bar{\pi}_{j}^{i}=v^{i}\left(\sum_{j} x_{j}^{i *}\left(t_{j}\right)\right)-\sum_{j} t_{j}^{i}\left(x_{j}^{i *}\left(t_{j}\right)\right)$, buyer $i$ 's payoff for profile $t$ is $\Pi^{i}\left(t^{i}, t^{-i}\right)=\sum_{j} \bar{\pi}_{j}^{i}$. Denote by $\bar{t}^{i}$, the $\bar{\pi}^{i}$-profit-target strategy of $i$. By the definition, $t_{j}^{i}\left(x_{j}^{i *}\left(t_{j}\right)\right)=\bar{t}_{j}^{i}\left(x_{j}^{i *}\left(t_{j}\right)\right)$ for all $i, j$, and $x_{j}^{i *}$. By $x_{j}^{*} \in \arg \max _{x_{j}} \Pi_{j}(t, x)$, we obtain $\sum_{i \in L_{j}(g)} t_{j}^{i}\left(x_{j}^{i}\right)+v_{j}\left(x_{j}^{0}\right) \leq \sum_{i \in L_{j}(g)} t_{j}^{i}\left(x_{j}^{i *}\left(t_{j}\right)\right)+v_{j}\left(x_{j}^{0 *}\left(t_{j}\right)\right)$.

Suppose that $\bar{t}_{j}^{i}\left(x_{j}^{i}\right)=0$ for some $x_{j}^{i}$. Then, by $0=\bar{t}^{i}\left(x_{j}^{i}\right) \leq t^{i}\left(x_{j}^{i}\right)$, we obtain

$$
\bar{t}_{j}^{i}\left(x_{j}^{i}\right)+\sum_{k \neq i} t_{j}^{k}\left(x_{j}^{k}\right)+v_{j}\left(x_{j}^{0}\right) \leq t_{j}^{i}\left(x_{j}^{i}\right)+\sum_{k \neq i} t_{j}^{k}\left(x_{j}^{k}\right)+v_{j}\left(x_{j}^{0}\right) \leq \bar{t}_{j}^{i}\left(x_{j}^{i *}\left(t_{j}\right)\right)+\sum_{k \neq i} t_{j}^{k}\left(x_{j}^{k *}\left(t_{j}\right)\right)+v_{j}\left(x_{j}^{0 *}\left(t_{j}\right)\right)
$$

Thus, $x_{j}^{i *}\left(\bar{t}_{j}^{i}, t_{j}^{-i}\right) \neq x_{j}^{i}$ for all $x_{j}^{i}$ with $\bar{t}_{j}^{i}\left(x_{j}^{i}\right)=0$. This implies that $\bar{t}_{j}^{i}\left(x_{j}^{i *}\left(\bar{t}_{j}^{i}, t_{j}^{-i}\right)\right)=f_{j}^{i}\left(x_{j}^{i *}\left(\bar{t}_{j}^{i}, t_{j}^{-i}\right)\right)-\bar{\pi}_{j}^{i}>0$. Hence,

$$
\Pi^{i}\left(\bar{t}_{j}^{i}, t_{j}^{-i}\right)=v^{i}\left(\sum_{j} x_{j}^{i *}\left(\bar{t}_{j}^{i}, t_{j}^{-i}\right)\right)-\sum_{j} \bar{t}_{j}^{i}\left(x_{j}^{i *}\left(\bar{t}_{j}^{i}, t_{j}^{-i}\right)\right)=\sum_{j} \bar{\pi}_{j}^{i}=\Pi^{i}\left(t^{i}, t^{-i}\right)
$$

Proposition 1 implies that the profit target strategy is a best response for any profile $t^{-i}$. The existence of Nash equilibria (NE) with profit target strategies is shown by construction in Proposition 2. We remark that the set of all NE payoff vectors with profit-target strategies is a proper subset of all NE payoff vectors.

Example 1. Consider a networked market with $b=2, s=1, N=1$, and $g=g^{c}=\{11,21\}$. Let $v_{1}=$ $10 x_{1}^{1}, v_{2}=5 x_{1}^{2}$, and $\omega_{1}=1$. Take any $\left(t_{1}^{1}, t_{1}^{2}\right)$ such that $\left(x_{1}^{1 *}(t), x_{1}^{2 *}(t)\right)=(1,0)$. Given $t_{1}^{1}, \bar{\pi}^{2}$-profit-target strategy $\bar{t}_{1}^{2}$ is the 0 -profit-target strategy for any best response $t_{1}^{2}$. Given $\bar{t}_{1}^{2}, \bar{\pi}_{1}^{1}$-profit-target strategy $\bar{t}_{1}^{1}$ is the 5-profit-target strategy for any best response $t_{1}^{1}$. Thus, in the NE with profit-target strategies $\left(\bar{t}_{1}^{1}, \bar{t}_{1}^{2}\right)$, the payoff vector is $(5,0,5)$. By the same argument, we can show that the $\left(\bar{t}_{1}^{1}, \bar{t}_{1}^{2}\right)$ is the unique $\mathrm{NE}$ with profit-target strategies. However, take a profile $\left(t_{1}^{1}, t_{1}^{2}\right)=\left(7 x_{1}^{1}, 7 x_{1}^{2}\right)$. Then $x_{1}^{*}(t)=(1,0)$. This profile yielding the payoff vector $(3,0,7)$ is an NE. Thus, $(3,0,7)$ supported by an NE is not supported 
by any NE with profit-target strategies.

\section{Equilibria and Bidder-Optimal Core}

To characterize the set of NE payoff vectors with profit-target strategies, we define a cooperative game $(M, g, w)$ in the networked market as follows. Let $M=I \cup J$ be a set of all buyers and all sellers, and $S \subset M$ be a coalition. Fix a network $g$. Let $g_{S}$ be a subnetwork for coalition $S$ such that $i j \in g_{S}$ if $i, j \in S$ and $i j \in g$, and $i j \notin g_{S}$ otherwise. Denote by $F\left(g_{S}\right)$, the set of $g_{S}$-feasible allocations. We define a characteristic function $w$ as for all $S \subset M$,

$$
w(S \mid g)=\max _{x \in F\left(g_{S}\right)} \sum_{i \in S} v^{i}\left(\sum_{j \in S} x_{j}^{i}\right)+\sum_{j \in S} v_{j}\left(x_{j}^{0}\right)
$$

Obviously, $w(S \mid g)$ is super-additive in coalition $S$. Thus, the core is defined as follows. We denote a payoff for $i$ and $j$ by $\phi^{i}$ and $\phi_{j}$, respectively.

Definition 4. The core of $(M, g, w)$ is given by

$$
\operatorname{Core}(M, g, w)=\left\{\phi \mid \sum_{i \in I} \phi^{i}+\sum_{j \in J} \phi_{j} \leq w(M \mid g)\right\} \cap\left\{\phi \mid \sum_{i \in I \cap S} \phi^{i}+\sum_{j \in J \cap S} \phi_{j} \geq w(S \mid g) \forall S \subset M\right\} .
$$

By definition, each payoff vector in the core is $g$-efficient. When $s=1$, the set of payoffs supported by an NE with profit-target strategies coincides with the bidder optimal core (Milgrom (2004, Theorem 8.7)). The following proposition shows that the above result can be extended to cases $s \geq 2$.

Definition 5. A payoff vector $\phi$ is bidder-optimal relative to $g$ if $\phi \in \operatorname{Core}(M, g, w)$ and there exists no $\phi^{\prime} \in \operatorname{Core}(M, g, w)$ with $\phi^{\prime i} \geq \phi^{i}$ for all $i \in I$ and $\phi^{i}>\phi^{i}$ for some $i \in I$. The set of bidder-optimal payoff vectors relative to $g$ is the bidder-optimal core relative to $g$.

Proposition 2. Fix a networked market $\left(\left(v^{i}, v_{j}, \omega_{j}\right)_{i, j \in M}, g\right)$.

(i) Suppose $\phi$ is bidder optimal relative to $g$. Then, any profile $t$ of $\pi^{i}$-profit-target strategies yielding the payoff vector $\phi$ constitutes an NE.

(ii) Conversely, suppose that profile $t$ of $\pi^{i}$-profit-target strategies yielding the payoff vector $\phi$ constitutes an NE. Then, $\phi$ is bidder optimal relative to $g$. 
Proof. Part (i): We show that if $\phi$ is bidder optimal then any profile $t$ of $\pi^{i}$-profit-target strategies yielding $\phi$ constitutes an NE. Take a profile $t$ of $\pi^{i}$-profit-target strategies yielding $\phi$ and let $x^{*}(t)$ be the corresponding allocation of sellers. Then $\sum_{j} \pi_{j}^{i}=\phi^{i}$ for all buyer $i$. By Proposition 1, it suffices to show that there is no deviation to another profit-target strategy $\hat{t}^{i}$.

Suppose that buyer $i \in L_{j}(g)$ deviates to $\hat{t}^{i}$ with $\hat{\pi}^{i}=\left(\pi_{j}^{i}+\delta, \pi_{-j}^{i}\right)$ for some seller $j \in L^{i}(g)(\delta>0)$. First, suppose $x_{j}^{i *}\left(t_{j}\right)=0$. Then $x_{j}^{i *}\left(\hat{t}_{j}^{i}, t_{j}^{-i}\right)=0$. Hence, the deviation is not profitable for buyer $i$.

Second, suppose $x_{j}^{i *}\left(t_{j}\right)>0$. If there exists no subcoalition $S$ such that $i \notin S, j \in S$, and $w(S \mid g)=$ $\sum_{k, l \in S}\left[\phi^{k}+\phi_{l}\right]$, then there exists $\delta>0$ such that $\left(\phi^{i}+\delta, \phi^{-i}, \phi_{j}-\delta, \phi_{-j}\right)$ which dominates $\phi$ for buyers is in $\operatorname{Core}(M, g, w)$. This contradicts that $\phi$ is bidder optimal.

Thus, since $\phi$ is bidder optimal, there exists a subcoalition $S$ such that $i \notin S, j \in S$, and $w(S \mid g)=$ $\sum_{k, l \in S}\left[\phi^{k}+\phi_{l}\right]$ for any buyer $i$ and any seller $j$. This implies

$$
\phi_{j}=\max _{\left\{x_{j} \mid x_{j}^{k}=0 \forall k \notin S\right\}} \sum_{k \in I} t_{j}^{k}\left(x_{j}^{k}\right)+v_{j}\left(x_{j}^{0}\right) .
$$

Then, we obtain for such coalition $S$,

$$
\begin{aligned}
\max _{\left\{x_{j} \mid x_{j}^{k}=0 \forall k \notin S\right\}} \sum_{k \in I} t_{j}^{k}\left(x_{j}^{k}\right)+v_{j}\left(x_{j}^{0}\right) & >\phi_{j}-\delta \\
& =\max _{x_{j}} \sum_{k \in I} t_{j}^{k}\left(x_{j}^{k}\right)+v_{j}\left(x_{j}^{0}\right)-\delta \\
& \geq \max _{\left\{x_{j} \mid x_{j}^{i}>0\right\}} \sum_{k \in I} t_{j}^{i}\left(x_{j}^{i}\right)+v_{j}\left(x_{j}^{0}\right)-\delta .
\end{aligned}
$$

This inequality shows that it is profitable for seller $j$ to exclude buyer $i \notin S$. Hence, $x_{j}^{i *}\left(\hat{t}_{j}^{i}, t_{j}^{-i}\right)=0$, and the payoff for $i$ decreases. Therefore, there is no profitable deviation for any buyer $i$.

Part (ii): To show the converse, suppose that profile $t$ of profit-target strategies and the corresponding $x^{*}(t)$ constitutes an NE with payoff vector $\phi$.

First, we show that $\phi \in \operatorname{Core}(M, g, w)$. Suppose $\phi \notin \operatorname{Core}(M, g, w)$. Then, there exists coalition $S$ such that $\sum_{i \in I \cap S} \phi^{i}+\sum_{j \in J \cap S} \phi_{j}<w(S \mid g)$. Since each buyer $i$ adopts profit-target strategy, $t_{j}^{i}\left(x_{j}^{i}\right)=$ 
$\max \left\{0, f_{j}^{i}\left(x_{j}^{i}\right)-\pi_{j}^{i}\right\}$. Then, we obtain for such $S$,

$$
\begin{aligned}
& \sum_{j \in J \cap S} \phi_{j}=\sum_{j \in J \cap S} \max _{x_{j}} \sum_{i \in I} t_{j}^{i}\left(x_{j}^{i}\right)+v_{j}\left(x_{j}^{0}\right) \\
& \geq \sum_{j \in J \cap S} \max _{\left\{x_{j} \mid x_{j}^{i}=0 \forall i \notin S\right\}} \sum_{i \in I} t_{j}^{i}\left(x_{j}^{i}\right)+v_{j}\left(x_{j}^{0}\right) \\
& \geq \sum_{j \in J \cap S} \max _{\left\{x_{j} \mid x_{j}^{i}=0 \forall i \notin S\right\}} \sum_{i \in I \cap S} f_{j}^{i}\left(x_{j}^{i}\right)-\pi_{j}^{i}+v_{j}\left(x_{j}^{0}\right) \\
& =\left[\sum_{j \in J \cap S} \max _{\left\{x_{j} \mid x_{j}^{i}=0 \forall i \notin S\right\}} \sum_{i \in I \cap S} f_{j}^{i}\left(x_{j}^{i}\right)+v_{j}\left(x_{j}^{0}\right)\right]-\sum_{i \in I \cap S} \phi^{i} \\
& =\left[\max _{\left\{x_{j} \mid x_{j}^{i}=0 \forall i \notin S\right\}} \sum_{i \in I \cap S} v^{i}\left(\sum_{j \in J} x_{j}^{i}\right)+\sum_{j \in J \cap S} v_{j}\left(x_{j}^{0}\right)\right]-\sum_{i \in I \cap S} \phi^{i} \\
& =w(S \mid g)-\sum_{i \in I \cap S} \phi^{i}>\sum_{j \in J \cap S} \phi_{j} .
\end{aligned}
$$

The fifth equality follows that $x_{j}^{i}=0$ for all $j \notin S$ and $\sum_{j \in J} f_{j}^{i}=v_{i}\left(\sum_{j \in J} x_{j}^{i}\right)$. This is a contradiction. Hence, $\phi \in \operatorname{Core}(M, g, w)$.

Next, we show that $\phi$ is bidder optimal. Let $\tilde{x}$ be the corresponding allocation to $\phi$. Suppose that $\phi$ is not bidder optimal. Then, there exists $(i, j)$ and $\delta>0$ such that $\tilde{\phi}=\left(\phi^{i}+2 \delta, \phi^{-i}, \phi_{j}-2 \delta, \phi_{-j}\right) \in$ $\operatorname{Core}(M, g, w)$. Suppose that buyer $i$ deviates to $\hat{\pi}^{i}$-profit-target strategy such that $\hat{\pi}^{i}=\left(\pi_{j}^{i}+\delta, \pi_{-j}^{i}\right)$ with $\sum_{l} \tau_{l}^{i}=\phi^{i}$, denoted by $\hat{t}^{i}=\left(\hat{t}_{j}^{i}, t_{-j}^{i}\right)$. Then, we obtain

$$
\begin{aligned}
\max _{x_{j}} \hat{t}_{j}^{i}\left(x_{j}^{i}\right)+\sum_{k \neq i} t_{j}^{k}\left(x_{j}^{k}\right)+v_{j}\left(x_{j}^{0}\right) & \geq \hat{t}_{j}^{i}\left(\tilde{x}_{j}^{i}\right)+\sum_{k \neq i} t_{j}^{k}\left(\tilde{x}_{j}^{k}\right)+v_{j}\left(\tilde{x}_{j}^{0}\right) \\
& =\phi_{j}-\delta>\phi_{j}-2 \delta .
\end{aligned}
$$

Let $S^{j}$ be any coalition such that $l \in S^{j}$ for all $l \leq j$ and $l \notin S^{j}$ for all $l>j$. Since $\left(\phi^{i}+2 \delta, \phi^{-i}, \phi_{j}-2 \delta, \phi_{-j}\right)$ is in $\operatorname{Core}(M, g, w)$,

$$
\begin{aligned}
\phi_{j}-2 \delta & \geq \max _{\left\{S^{j} \mid i \notin S^{j}\right\}} w\left(S^{j} \mid g\right)-\sum_{k \in I \cap S^{j}} \phi^{k}-\sum_{l \in J \cap S^{j} \backslash\{j\}} \phi_{l} \\
& =\max _{\left\{S^{j} \mid i \notin S^{j}\right\}}\left[\max _{x} \sum_{k \in I \cap S^{j}} v^{k}\left(\sum_{l \leq j} x_{l}^{k}\right)+\sum_{l \leq j} v_{l}\left(x_{l}^{0}\right)\right]-\sum_{k \in I \cap S^{j}} \phi^{k}-\sum_{l<j} \phi_{l} \\
& \geq \max _{\left\{S^{j} \mid i \notin S^{j}\right\}}\left[\max _{x_{j}} \sum_{k \in I \cap S^{j}} v^{k}\left(x_{j}^{k}+\sum_{l<j} \tilde{x}_{l}^{k}\right)+v_{j}\left(x_{j}^{0}\right)+\sum_{l<j} v_{l}\left(\tilde{x}_{l}^{0}\right)\right]-\sum_{k \in I \cap S^{j}} \phi^{k}-\sum_{l<j} \phi_{l} .
\end{aligned}
$$


Substituting $\phi^{k}=\sum_{l \in S^{j}} \pi_{l}^{k}$ and $\phi_{l}=\sum_{k}\left[v^{k}\left(\tilde{x}_{l}^{k}+\sum_{m<l} \tilde{x}_{m}^{k}\right)-v^{k}\left(\sum_{m<l} \tilde{x}_{m}^{k}\right)+v_{l}\left(\tilde{x}_{l}^{0}\right)-\pi_{l}^{k}\right]$ into it yields

$$
\begin{aligned}
& \max _{\left\{S^{j} \mid i \notin S^{j}\right\}}\left[\max _{x_{j}} \sum_{k \in I \cap S^{j}} v^{k}\left(x_{j}^{k}+\sum_{l<j} \tilde{x}_{l}^{k}\right)+\sum_{l<j} v_{l}\left(\tilde{x}_{l}^{0}\right)+v_{j}\left(x_{j}^{0}\right)\right]-\sum_{k \in I \cap S^{j}} \phi^{k}-\sum_{l<j} \phi_{l} \\
& =\max _{x_{j}} \max _{\left\{S^{j} \mid i \notin S^{j}\right\}} \sum_{k \in I \cap S^{j}}\left[\left(v^{k}\left(x_{j}^{k}+\sum_{l<j} \tilde{x}_{l}^{k}\right)-\pi_{j}^{k}-v^{k}\left(\sum_{l<j} \tilde{x}_{l}^{k}\right)\right]+v_{j}\left(x_{j}^{0}\right)\right. \\
& \quad=\max _{x_{j}} \sum_{k \neq i}\left[\max \left\{0, v^{k}\left(x_{j}^{k}+\sum_{l<j} \tilde{x}_{l}^{k}\right)-v^{k}\left(\sum_{l<j} \tilde{x}_{l}^{k}\right)-\pi_{j}^{k}\right\}\right]+v_{j}\left(x_{j}^{0}\right) \\
& =\max _{x_{j}} \sum_{k \neq i} t_{j}^{k}\left(x_{j}^{k}\right)+v_{j}\left(x_{j}^{0}\right) .
\end{aligned}
$$

Therefore, $\phi_{j}-2 \delta \geq \max _{x_{j}}\left[\sum_{k \neq i} t_{j}^{k}\left(x_{j}^{k}\right)+v_{j}\left(x_{j}^{0}\right)\right]$. This inequality implies that seller $j$ 's payoff decreases if $j$ rejects buyer $i$ 's $\left(\pi_{j}^{i}+\delta\right)$-profit-target strategy. Thus, since seller $j$ accepts the buyer $i$ 's deviation, it is profitable for buyer $i$. This contradicts the assumption that profile $t$ is an NE. Hence, $\phi$ is bidder optimal.

Remark 1. Consider the following sequential first price package auction. First, sellers are ordered at random and renamed according to the order. In Stage 1.1, each buyer bids schedules to seller 1. In Stage 1.2, seller 1 decides an allocation. In Stage 2.1, each buyer bids schedules to seller 2, and so on. Since valuations are private, there exists a subgame perfect equilibrium with profit-target strategies which is payoff equivalent to an NE with profit-target strategies of the first price package auction.

By Proposition 2, NE allocation $x^{*}(t)$ is g-efficient for any $g$, where $t$ is an NE bidding profile with $\pi^{i}$-profit-target strategies. Thus, any $g$-efficient outcome yielding a bidder optimal payoff vector is implemented by the first price package auction mechanism for any $g$.

\section{Comparison with Other Market Mechanisms}

\subsection{Substitutes and VCG outcome}

This section studies a relation between the decentralized first price package auction mechanism resulting in the bidder optimal core and the centralized Vickrey-Clark-Groves (VCG) mechanism. In what follows, we assume that each seller has no valuation over any package (i.e. $\left.v_{j}(x) \equiv 0\right)$ for 
simplification. Milgrom (2004) shows that, whenever $s=1$, the bidder-optimal payoff vector is unique and coincides with the VCG payoff vector, and then the VCG payoff vector is in the core, if valuations satisfy concavity ${ }^{3}$ and a substitute condition. ${ }^{4}$

In the VCG mechanism, there is a unique planner. Each buyer $i$ reports valuation $\hat{v}^{i}$ to the planner (valuations of sellers are known). Then, the planner imposes a $g$-feasible allocation of commodities and transfer. It is well-known that each buyer $i$ earns $i$ 's marginal contribution $w(M \mid g)-w(M \backslash\{i\} \mid g)$ in the truthful equilibrium with dominant strategies of the VCG mechanism. We denote buyer i's and seller j's VCG payoffs by $\phi_{V}^{i}(g)$ and $\phi_{j V}(g)$, and $i$ 's and $j$ 's bidder optimal payoffs by $\phi_{B}^{i}(g)$ and $\phi_{j B}(g)$ for any $g \in G$, respectively. Let $\phi_{V}=\left(\phi_{V}^{i}, \phi_{j V}\right)_{i, j \in M}$ and $\phi_{B}=\left(\phi_{B}^{i}, \phi_{j B}\right)_{i, j \in M}$.

Proposition 3. For any $i$ and any $g, \phi_{V}^{i}(g) \geq \max \left\{\phi_{B}^{i}(g)\right\}$, and $\sum \phi_{j V}(g) \leq \min \left\{\sum \phi_{j B}(g)\right\}$.

Proof. Any payoff vector such that some buyer i's payoff is strictly greater than i's marginal contribution is not in core. Thus, i's VCG payoff $\phi_{V}^{i}(g)$ is greater than or equal to $i$ 's maximum payoff $\max \left\{\phi_{B}^{i}(g)\right\}$ in the bidder optimal core. Since $\sum_{i, j}\left[\phi_{V}^{i}(g)+\phi_{j V}(g)\right]=\sum_{i, j}\left[\phi_{B}^{i}(g)+\phi_{j B}(g)\right]=w(M \mid g)$, we obtain $\sum \phi_{j V}(g) \leq \min \left\{\sum \phi_{j B}(g)\right\}$.

If Proposition 4 holds with equalities, then the payoff equivalence holds true as $s=1$. In the following example, equalities hold.

Example 2. Let $I=\{1,2,3\}, J=\{1,2\}, N=1$, and $g=g^{c}$ (complete bipartite graph). Suppose that $\omega_{j}=1$ for all $j$. Each buyer has a valuation function given in Table 1. Each $v_{i}$ is concave and linear-substitute valuation for $i=1,2,3$. The marginal contribution of buyer 1,2 , and 3 are given by $2,1,0$, respectively. Hence, $\left(\phi_{V}^{1}, \phi_{V}^{2}, \phi_{V}^{3}\right)=(2,1,0)$. The bidder optimal payoff vector for buyers is uniquely given by $\left(\phi_{B}^{1}, \phi_{B}^{2}, \phi_{B}^{3}\right)=(2,1,0)$. This example demonstrates that each buyer $i=1,2$ earns $i$ 's marginal contribution, which is the VCG payoff, in the auction.

The next example, however, shows a strict inequity even if the substitute condition holds for buyers.

\footnotetext{
${ }^{3}$ We additionally require concavity since commodities are divisible. The equivalence holds true when valuation functions are concave nonlinear-substitute valuations for divisible goods. If we consider multiple indivisible commodities, the strong-substitute property is sufficient. See Milgrom and Strulovici (2009) for details.

${ }^{4}$ Formally, we denote a price vector over commodities $N$ by $p=\left(p^{n}\right)_{n \in N}\left(p^{n} \in \mathbb{R}_{+}\right)$. A demand correspondence for agent $i$ is given by $D^{i}(p)=\arg \max v^{i}\left(\sum_{j} y_{j}^{i}\right)-\sum_{j} p \cdot y_{j}^{i}$. Valuation $v^{i}$ is linear-substitute if whenever $p^{n} \leq \tilde{p}^{n}, p^{-n}=\tilde{p}^{-n}$, and $x \in D^{i}(p)$, there exists $\tilde{x} \in D^{i}(\tilde{p})$ such that $x^{-n} \leq \tilde{x}^{-n}$. The linear-substitute and the nonlinear-substitute conditions are equivalent for concave valuations.
} 


\begin{tabular}{c|ccc} 
& $v^{1}$ & $v^{2}$ & $v^{3}$ \\
\hline $0 \leq x \leq 1$ & $10 x$ & $9 x$ & $8 x$ \\
$1<x \leq 2$ & $10+8(x-1)$ & $9+7(x-1)$ & $8+6(x-1)$ \\
$2<x$ & 18 & 16 & 14
\end{tabular}

Table 1: Valuation functions for buyers

Example 3. Let $I=\{1,2\}, J=\{1,2\}, N=1$, and $g=g^{c}$. Suppose that $\omega_{j}=1$ for all $j$. The valuation function for buyers are also given in Table 1. The marginal contributions of buyer 1 and 2 are 3 and 1 respectively. Thus, $\left(\phi_{V}^{1}, \phi_{V}^{2}\right)=(3,1)$. However, the set of bidder optimal payoff vector for buyers $\left(\phi_{B}^{1}, \phi_{B}^{2}\right)$ is $\{(2,1)\}$. This example demonstrates that in the auction, each buyer $i=1,2$ earns a less payoff than $i$ 's marginal contribution while goods are substitutes for buyer $i=1,2$.

Thus, when $s \geq 2$, the payoff equivalence fails even if buyers' valuations are substitute. The VCG payoff vector Pareto-dominates any bidder optimal payoff vector for buyers, and thus is not in the core.

Corollary 1. Suppose $s \geq 2$. Then, the VCG payoff vector is not in the core, even if buyers' valuations are concave and substitute.

\subsection{Competitive Equilibrium}

This section studies a relation to the competitive equilibrium, which is a standard stable outcome when traders are price-takers. In addition, Cripps and Swinkels (2006) show that the centralized Double auction implements the competitive equilibrium. In Example 2, the minimal competitive price $p=8$ and the corresponding payoff vector for buyers is $(2,1,0)$. Since the unique bidder optimal payoff vector for buyers is $(2,1,0)$, there is a competitive equilibrium payoff vector in the bidder optimal core. Example 3 also has this relation. However, it fails in the following example.

Example 4. Let $I=\{1,2,3\}, J=\{1,2\}, N=1$, and $g=g^{c}$. Suppose that $\omega_{j}=2$ for all $j$. The valuation function for buyers are also given in Table 1. The minimal competitive price is 7 . The corresponding competitive payoff vector for buyers is $(4,2,1)$. However, the set of bidder optimal payoff vectors for buyers is $\{(5,3,1)\}$. This example demonstrates that each buyer $i=1,2,3$ earns a greater payoff than $i$ 's maximal competitive payoff in the auction. 
To investigate the relation formally, we introduce a link-based price vector $\left(p_{j}^{i}\right)_{i \in I, j \in J}$ into the networked market $g$. Each $p_{j}^{i}(g) \in \mathbb{R}_{+}^{N}$ is a price vector between buyer $i$ and seller $j$. If buyer $i$ buys $x_{j}^{i}$ from seller $j$, then $i$ pays $p_{j}^{i}(g) x_{j}^{i}$ to $j$.

Definition 6. $\left(p_{j}^{i}(g), x_{j}^{i}(g)\right)_{i \in I, j \in J}$ is a competitive equilibrium relative to $g$ ( $g$-competitive equilibrium) if for all $i$ and all $j$,

(i) $\left(x_{1}^{i}(g), \ldots, x_{s}^{i}(g)\right) \in \arg \max v^{i}\left(\sum_{j} y_{j}^{i}\right)-\sum_{j} p_{j}^{i}(g) y_{j}^{i}$ subject to $y_{j}^{i}=0$ for all $i j \notin g$, and

(ii) $\left(x_{j}^{1}(g), \ldots, x_{j}^{b}(g)\right) \in \arg \max \sum_{i} p_{j}^{i}(g) y_{j}^{i}$ subject to $y_{j}^{i}=0$ for all $i j \notin g$ and $\sum_{i} y_{j}^{i} \leq \omega_{j}$.

Let $\phi_{C}^{i}(g)$ and $\phi_{j C}(g)$ be $i$ 's and $j$ 's $g$-competitive payoffs respectively, and $\phi_{C}=\left(\phi_{C}^{i}, \phi_{j C}\right)_{i, j \in M}$. The following standard property of the competitive equilibrium holds in the networked market.

Lemma 1. $\phi_{C}(g) \in \operatorname{Core}(M, g, w)$.

Proof. Fix $g$. Let $\left(p_{j}^{i}, x_{j}^{i}\right)_{i \in I, j \in J}$ be a competitive equilibrium, and let $p_{j}$ be a vector with $p_{j n}=\max _{i \in L_{j}(g)} p_{j n}^{i}$ for all $n=1, \ldots, N$. Since $\left(x_{j}^{i}\right)_{i \in I} \in \arg \max _{y_{j}^{i}} \sum_{i} p_{j}^{i} y_{j}^{i}$ for all $j$, we obtain $\sum_{i} p_{j}^{i} x_{j}^{i}=p_{j} \omega_{j}$ for all $i, j$.

Take any coalition $S$. Suppose that there exists $\left(\tilde{x}_{j}^{i}\right)_{i, j \in S}$ such that $v^{i}\left(\sum_{j \in S} \tilde{x}_{j}^{i}\right)-\sum_{j \in S} p_{j} \tilde{x}_{j}^{i}>\phi_{C}^{i}(g)$ and $\sum_{i \in S} p_{j} \tilde{x}_{j}^{i}>\phi_{j c}(g)$ for all $i, j \in S$. Then, $\sum_{i \in S} p_{j} \tilde{x}_{j}^{i}>\sum_{i} p_{j}^{i} x_{j}^{i}=p_{j} \omega_{j}$ for all $j \in S$. Hence, $\sum_{i, j \in S} p_{j} \tilde{x}_{j}^{i}>$ $\sum_{j \in S} p_{j} \omega_{j}$. However, $\sum_{i, j \in S} \tilde{x}_{j}^{i}<\sum_{j \in S} \omega_{j}$ by feasibility. This is a contradiction. Thus, there is no coalition $S$ such that $\sum_{i \in S} \phi_{C}^{i}(g)+\sum_{j \in S} \phi_{j C}(g)<w(S \mid g)$.

By definition, we obtain the following straightforwardly.

Proposition 4. There exists $\left(\phi_{B}^{i}(g)\right)_{i \in I}$ such that $\phi_{B}^{i}(g) \geq \phi_{C}^{i}(g)$ for all $i, g$, and $\left(\phi_{C}^{i}(g)\right)_{i \in I}$. Moreover, $\max \left\{\sum \phi_{j B}(g)\right\} \leq \min \left\{\sum \phi_{j c}(g)\right\}$.

Example 4 shows that a strict inequality holds in some networked market. Thus, the first price package auction mechanism does not implement the competitive equilibrium, and any competitive equilibrium is Pareto-dominated by a bidder optimal outcome for buyers. 


\section{Discussion}

\subsection{Coalition-proofness of equilibria}

In the auction with a single seller $(s=1)$, Bernheim and Whinston (1986) show that the set of NEs with profit-target strategies yielding a bidder-optimal payoff vector is equal to the set of coalitionproof Nash equilibria. Thus, the bidder optimal core is equal to it. In this section, we extend this result to the auction with multiple sellers, $s \geq 2$.

To show it, we define a component game relative to coalition $S$ with $J \subsetneq S \subsetneq M$ as follows: For any bidding profile $t$, let $t^{S}=\left(t^{i}\right)_{i \in S \cap I}$. The component game is given by $\Gamma / t^{M \backslash S}=\left(\left(t^{i}, \tilde{\Pi}^{i}\right)_{i \in S}\right)$, where $\tilde{\Pi}^{i}=\Pi^{i}\left(t^{S \cap I}, \tilde{t}^{M \backslash S}\right)$.

Definition 7. Fix a networked market $\left(\left(v^{i}, v_{j}, \omega_{j}\right)_{i, j \in M}, g\right)$.

(i) In a first price package auction $\Gamma$ with a single buyer $(b=1)$ and $s$ sellers $(s \geq 1)$, profile $t^{1}$ is a coalition-proof Nash equilibrium (CPNE) if it is an NE.

(ii) (a) For a first price package auction $\Gamma$ with $b$ buyers $(b \geq 2)$ and $s$ sellers, profile $t^{M}$ is self-enforcing if for any coalition $S$ with $J \subseteq S \subsetneq M$, profile $t^{S}$ is a CPNE in the component game relative to $S, \Gamma / t^{M \backslash S}$.

(b) For any first price package auction $\Gamma$ with a set $S$ of buyers and sellers, profile $t^{M}$ is a CPNE if it is self-enforcing, and it does not Pareto-dominated by another selfenforcing profile.

Proposition 5. The bidder-optimal core is equal to the set of CPNE payoff vectors.

Proof. Fix $s \geq 1$. In any auction with a single buyer $(b=1)$, it is obvious that the unique NE yielding the unique bidder-optimal payoff vector is a CPNE.

Assume that the proposition holds true in any auction with $b=1, \ldots, m$ buyers and $s$ sellers. Consider an auction with $m+1$ buyers and s sellers. By Proposition 2, for any bidder-optimal payoff vector $\phi$, there is an NE $t$ with profit-target strategies yielding $\phi$.

We first show that any bidder optimal $\phi$ is supported by a CPNE. Take an NE $t$ with profit-target strategies yielding bidder optimal $\phi$. Since $t$ is a profile of profit-target strategies, for any $S$ and any 
seller $j$, in the component game $\Gamma / t^{M \backslash S}$,

$$
x_{j}^{*}\left(t^{S}, t^{M \backslash S}\right) \in \arg \max _{\sum_{i} x_{j}^{i} \leq \omega_{j}} v_{j}^{0}\left(x_{j}^{0}\right)+\sum_{i} v^{i}\left(x_{j}^{i}+\sum_{l<j} x_{l}^{k *}\left(t^{S}, t^{M \backslash S}\right)\right)
$$

Thus, in component game $\Gamma / t^{M \backslash S}$, each seller $j$ chooses the same $x_{j}^{*}(t)=x_{j}^{*}\left(t^{S}, t^{M \backslash S}\right)$ as in the game $\Gamma$. Hence, $\left(\phi^{i}, \phi_{j}\right)_{i, j \in S}$ is bidder optimal in $\Gamma / t^{M \backslash S}$. Since the proposition holds true for $b=1, \ldots, m$, profile $t^{S}$ is a CPNE in $\Gamma / t^{M \backslash S}$ for any $S \subsetneq M$. Thus, $t$ is self-enforcing. Since $\phi$ is bidder optimal, $t$ is not Pareto-dominated by another self-enforcing profile. Hence, $t$ is a CPNE. By mathematical induction, any NE $t$ yielding bidder optimal $\phi$ is a CPNE for any $b \in \mathbb{N}$.

We next show that any CPNE payoff vector is bidder-optimal. Take a CPNE $t$ yielding $\phi$. Since the proposition holds true for $b=1, \ldots, m$, payoff vector $\left(\phi^{i}, \phi_{j}\right)_{i, j \in S}$ is bidder optimal in component game $\Gamma / t^{M \backslash S}$ for any $S \subsetneq M$. Suppose that payoff vector $\phi$ is not bidder optimal in game $\Gamma$. Then, there exists $\hat{\phi}$ that Pareto-dominates $\phi$ for buyers in some coalition $S$ with $J \subsetneq S \subsetneq M$. Hence, $\phi$ is not bidder optimal in component game $\Gamma / t^{M \backslash S}$. However, $\left(\phi^{i}, \phi_{j}\right)_{i, j \in S}$ is bidder optimal in $\Gamma / t^{M \backslash S}$. This is a contradiction. Thus, $\phi$ is bidder optimal.

By mathematical induction, any CPNE payoff vector is bidder-optimal for any $b \in \mathbb{N}$.

Applying the above argument for any number of sellers $s \in \mathbb{N}$ shows that the bidder optimal core is equivalent to the set of CPNE payoff vectors for any $b$, $s$.

\subsection{Stability of Networks}

We have investigated the allocation problem on a given network. This section discusses efficiency and stability of networks, provided that the selling mechanism is the first price package auction. Denote by $\eta^{i}$ and $\eta_{j}$, numbers of links of $i$ and $j$ in $g$ respectively. Let $L$ be a link-based transaction cost function to form network $g$. We assume that $L(g)=\sum_{i} l^{i} \eta^{i}(g)+\sum_{j} l_{j} \eta_{j}(g)$, where $l^{i}$ and $l_{j}$ are some constants for buyer $i$ and seller $j$ respectively. Thus, social welfare in network $g$ is given by $W(g)=w(M \mid g)-L(g)$. The network $g$ is efficient if $g \in \arg \max _{g^{\prime}} W\left(g^{\prime}\right)$.

Let $g+i j$ be a network given by adding link $i j \notin g$ to $g$, and $g-i j$ be a network given by deleting $i j \in g$ from $g$. Then if $g$ is efficient, $w(M \mid g+i j)-w(M \mid g) \leq L(g+i j)-L(g)=l^{i}+l_{j}$ for all $i j \notin g$ and 
$w(M \mid g)-w(M \mid g-i j) \geq L(g)-L(g-i j)=l^{i}+l_{j}$ for all $i j \in g$.

First, we develop a model of unilateral formation of networks. Each buyer $i$ unilaterally forms a link with any seller $j$ with whom $i$ wants to link at cost $l^{i}>0$ for all $i$. For all seller $j, l_{j}=0$. A network $g$ is unilaterally stable if there exists a bidder-optimal payoff vector $\phi_{B}$ such that

(i) for $i j \in g, \phi_{B}^{i}(g)-\phi_{B}^{i}(g-i j) \geq l^{i}$, and

(ii) for $i j \notin g, \phi_{B}^{i}(g+i j)-\phi_{B}^{i}(g) \leq l^{i}$.

Proposition 6. Any efficient network is unilaterally stable.

Proof. Take an efficient network $g$ and a payoff vector $\phi_{B}(g)$. By definition, $w(S \mid g)=w(S \mid g-i j)$ for any coalition $S \nexists i$. By bidder optimality, this implies that for all $i$ and all $i j \in g$, there exist bidder optimal $\phi_{B}(g)$ and $\phi_{B}^{i}(g-i j)$ such that

$$
\phi_{B}^{i}(g)=\phi_{B}^{i}(g-i j)+[w(M \mid g)-w(M \mid g-i j)]
$$

Since $g$ is efficient, $\phi_{B}^{i}(g)-\phi_{B}^{i}(g-i j)=w(M \mid g)-w(M \mid g-i j) \geq l^{i}$. Thus, any efficient $g$ satisfies the condition (i). Applying the same derivation for $i j \notin g$ yields that $\phi_{B}^{i}(g)-\phi_{B}^{i}(g+i j)=w(M \mid g)-w(M \mid g+$ $i j) \geq-l^{i}$ for all $i j \notin g$. Thus, the condition (ii) is satisfied. Hence, any efficient network is stable.

Next, we model a bilateral formation of networks. A link ij is formed if and only if both $i$ and $j$ agree with forming link $i j$. We allow side-payments between $i$ and $j$ to form link $i j$. A network $g$ satisfies pairwise stability with side-payments if

(i) for $i j \in g,\left[\phi_{B}^{i}(g)-\phi_{B}^{i}(g-i j)\right]+\left[\phi_{j B}(g)-\phi_{j B}(g-i j)\right] \geq l^{i}+l_{j}$, and

(ii) for $i j \notin g,\left[\phi_{B}^{i}(g+i j)-\phi_{B}^{i}(g)\right]+\left[\phi_{j B}(g+i j)-\phi_{j B}(g)\right] \leq l^{i}+l_{j}$.

If an efficient network $g$ is pairwise stable, then the payoff increase of seller $j$ by forming a new link $i j \notin g$ is smaller than the decrease of social welfare; $\phi_{j B}(g+i j)-\phi_{j B}(g) \leq[L(g+i j)-L(g)]-[w(M \mid g+$ $i j)-w(M \mid g)]=W(g)-W(g+i j)$. Thus, if $\phi_{j B}(g+i j)-\phi_{j B}(g)>W(g)-W(g+i j)$ for any $i j \notin g$, then efficient network $g$ is not pairwise stable.

Example 5 (Efficient but not pairwise stable network). Suppose that all buyers are symmetric $\left(v^{i}=v\right.$ for all $i$ ), all sellers are symmetric and have no value on bundles $\left(v_{j} \equiv 0\right.$ and $\omega_{j}=\omega$ for all $\left.j\right)$, and $b=s$. Let the link cost $l$ be relatively low such that $v(2 \omega)-v(\omega)>2 l$. Then, the unique 
architecture of an efficient network is $g=\{11,22, \ldots, s s\}$. Given $g$, each seller $j$ obtains no surplus $\left(\phi_{j B}(g)=0\right)$. If seller $j$ forms a link $i j$ with $i(i j \notin g)$, then $j$ earns $\phi_{j B}(g+i j)=v(2 \omega)-v(\omega)$. Since $\phi_{j}(g+i j)-\phi_{j}(g)=v(2 \omega)-v(\omega)>2 l$ and $\phi^{i}(g+i j)-\phi^{i}(g)=0$ for any $i j \notin g$, a pair $(i, j)$ forms a new link $i j \notin g$. Hence, any efficient network is not pairwise stable.

A sufficient condition that an efficient network is pairwise stable is given as follows.

Proposition 7. Suppose the complete network $g^{c}$ is an efficient network. Then, it is pairwise stable.

Proof. By (5), there exists $\left(\phi_{B}(g)\right)_{g \in G}$ such that $\phi_{B}^{i}(g)-\phi_{B}^{i}(g-i j)=w(M \mid g)-w(M \mid g-i j)$ and $\phi_{j B}(g)-$ $\phi_{j B}(g-i j) \geq 0$ for all $g$. Since $g^{c}$ is efficient, $\phi_{B}^{i}\left(g^{c}\right)-\phi_{B}^{i}\left(g^{c}-i j\right)+\phi_{j B}\left(g^{c}\right)=\phi_{j B}\left(g^{c}-i j\right) \geq l^{i}+l_{j}$ for any $i j \in g^{c}$. Thus, $g^{c}$ satisfies the condition (i). Since there is no $i j \notin g^{c}$, the condition (ii) is satisfied.

A networked market with no link cost is an obvious example. If $l^{i}=l_{j}=0$ for all $i, j$, it is obvious that the complete network is efficient and thus pairwise stable. In addition, both right-hand-sides of the conditions (i) and (ii) of pairwise stability are zero. Since $\phi^{i}(g+i j) \geq \phi^{i}(g)$ and $\phi_{j}(g+i j) \geq \phi_{j}(g)$, the efficient complete network is pairwise stable.

\section{Concluding remarks}

We have studied the first price package auction in the decentralized networked two-sided market. We show that the results shown by Bernheim and Whinston (1986) hold true in the auction with multiple sellers. There exist equilibria with profit target strategies, where each buyer bids truthfully, and the set of these equilibrium payoff vectors is equal to the bidder optimal core relative to an exogenously given network. However, the payoff equivalence to the VCG outcome does not hold. We show that the bidder optimal payoff vector is Pareto-dominated by the VCG payoff vector for buyers even if commodities are substitutes for all buyers. We also show that the bidder optimal payoff vector Pareto-dominates the competitive equilibrium payoff vector for buyers.

Further investigation will be necessary since our study has the following three limitations. The first is information structure. Throughout the paper, we have assumed complete information among all buyers and all sellers. Buyers and sellers, however, usually have private information for their valuations or endowments in auctions. The second is optimality. We have assumed that all sellers 
sell endowments using the first price package auction. However, it would not be an optimal selling mechanism for sellers. The third is strategic complexity. In the first price package auction, each buyer bids a menu, which is a collection of a payment of any possible package. The package auction might be complex rather than a multi-round auction where buyers bid each commodity individually in each round. Analyzing the package auction with private information, the optimal package auction, and the multi-round simple package auction in decentralized two-sided networked markets are left for future research.

\section{References}

S. Anwar, R. McMillan, and M. Zheng. "Bidding behavior in competing auctions: Evidence from eBay”. In: European Economic Review 50.2 (Feb. 2006), pp. 307-322. DoI: 10. 1016/j. euroecorev . 2004.10 .007 (cit. on p. 2).

L. M. Ausubel and P. R. Milgrom. "Ascending Auctions with Package Bidding”. In: The B.E. fournal of Theoretical Economics 1.1 (Aug. 2002). Dor: 10.2202/1534-5955.1019 (cit. on p. 1).

B. D. Bernheim and M. D. Whinston. "Menu Auctions, Resource Allocation, and Economic Influence”. In: The Quarterly fournal of Economics 101.1 (Feb. 1986), pp. 1-32 (cit. on pp. 1, 14, 17).

M. Corominas-Bosch. "Bargaining in a network of buyers and sellers". In: fournal of Economic Theory 115.1 (2004), pp. 35-77 (cit. on p. 2).

P. Cramton, Y. Shoham, and R. Steinberg. Combinatorial Auctions. The MIT Press, 2006 (cit. on p. 1).

M. W. Cripps and J. M. Swinkels. "Efficiency of Large Double Auctions". In: Econometrica 74.1 (2006), pp. 47-92. DoI: doi: 10.1111/j.1468-0262.2006.00649.x (cit. on p. 12).

R. E. Kranton and D. F. Minehart. "A Theory of Buyer-Seller Networks”. In: The American Economic Review 91.3 (June 2001), pp. 485-508 (cit. on p. 2).

P. Milgrom. Putting Auction Theory to Work. 1st ed. Cambridge University Press, 2004 (cit. on pp. 2, $7,11)$.

P. Milgrom and B. Strulovici. "Substitute goods, auctions, and equilibrium". In: fournal of Economic Theory 144.1 (2009), pp. 212-247. Dor: 10.1016/j.jet.2008.05.002 (cit. on p. 11). 
M. Peters and S. Severinov. "Internet auctions with many traders". In: Fournal of Economic Theory 130.1 (Sept. 2006), pp. 220-245. Dor: 10.1016/j.jet.2005.04.005 (cit. on p. 2). 
This Discussion Paper Series is published by the Center for Business Creation(changed from the Institute of Economic Research on April 1999) and integrates two old ones published separately by the Department of Economics and the Department of Commerce.

Discussion Paper Series

Institute of Economic Research

0 taru University of Commerce

No.

Tit 1 e

1.ホーキンズ=任の条件に関する諸説の統 合について

2. Motivation and Causal Inferences in the Budgetary Control

3. П р о б с и л

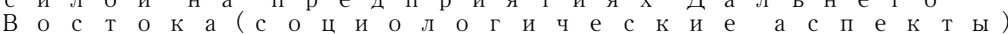

4. Dynamic Tax Incidence in a Finite Horizon Model

5. Business Cycles with Asset Price Bubbles and the Role of Monetary Policy

6. Continuous Double-Sided Auctions in Foreign Exchange Markets

7. The Existence of Ramsey Equilibrium with Consumption Externality

8. Money, Neutrality of Consumption Taxes, and Growth in Intertemporal 0ptimizing Models

9. Product Returns in the Japanese Distribution System:A Case Study of a Japanese Wholesaler's Return Reduction Efforts

10. Dynamics, Consistent Conjectures and Heterogeneous Agents in the Private Provision of Public Goods

11. Intra-industry Investment and Imperfect Markets A Geometric approach in Simple General Equilibrium

12. Sit-Down to Split:Flint GM Workers in 1937-1939

13. The Complementarity between Endogenous Protection and Direct foreign Investment

14. Consumption Taxation and Tax Prepayment approach in Dynamic General equilibrium Models with Consumer Durables

15. Regulatory System and Supervision of the Financia 1 Institutions in Japan

16. Financial Restructuring and the U. S. Regulatory Framework

17. The Legacy of the Bubble Economy in Japan:Declining cross Shareholding and Capital Formation

18. Stockownership in the U. S. Capital Formation and Regulation

19. International Joint Ventures and Endogenous Protection a Political-Economy Approach

20. GM社をめぐるアメリカ労働史研究：ファインとエッッ゙フォースの現場像の吟味

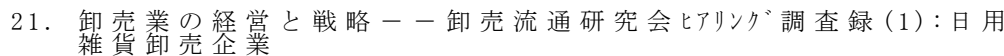

22. 卸売業の経営と戦略- - 卸売流通研究会坆ング調査録 $(2)$ : 食品・

23. A Note on the Impacts of Price Shocks on Wage in Unionized Economies

24. Transfer Pricing and the Nature of the subsidiary firm

25. The Incidence of a Tax on Pure in an Altruistic 0verlapping Generations Economy

26. 'Smal1 Government' in the $21 \mathrm{st}$ Century

27. Characteristics and Reforms of Public Health Insurance System in Japan

28. The Role of Local Governments in Urban Development Policy

29. Optimal Taxation and the Private Provision of Public Goods

30. Comparison of Agricultural Policy in the U. S. and the Japan

31. US Health Insurance:Types, Patterns of Coverage and Constraints to Reform

32. International Capital Flows and National Macroeconomic Policies

33. Financial Liberalization and Securitization in Housing Finance and the Changing Roles of the Government

34. Social Efficiency and the 'Market Revolution' in US Housing Finance

35. Government Expenditure and the Balance of Payments:Budget Deficit, Financial Integration, and Economic Diplomacy

36. A History of $P B G C$ and Its Roles

37. Dynamic Provision of Public Goods as Environmental Externalities

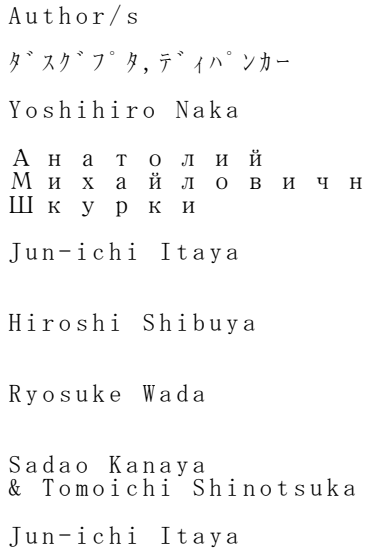

Jeffery Alan Brunson

Jun-ichi Itaya

\& Dipankar Dasgupta

Laixun Zhao

Satoshi Takata

Laixun Zhao

Jun-ichi Itaya

0 samu Ito

Jane W. D'Arista

Hiroo Hojo

Marsha11 E. B1ume

Laixun Zhao

高田聡

卸売流通研究会城朝則)

卸売流通研究会城朝則)

Laixun Zhao

Laixun Zhao

Jun-ichi Itaya

Hiroshi Shibuya

Takashi Nakahama

Yoshinori Akiyama

Jun-ichi Itaya

\& David de Meza

Toshikazu Tateiwa

Dwayne A. Banks

Jane W. D’Arista

Syn-ya Imura

Gary Dymski

\& Dorene Isenberg

Hiroshi Shibuya

C. David Gustafson

Toshihiro Ihori

\& Jun-ichi Itaya
Date

Ju 1.1992

Aug. 1992

Nov. 1992

Jan. 1993

Jun. 1993

Aug. 1993

Sep. 1993

Nov. 1993

Mar. 1994

Jun. 1994

0ct. 1994

Dec. 1994

Feb. 1995

Mar. 1995

May 1995

May 1995

May 1995

May 1995

Nov. 1995

Feb. 1996

Apr. 1996

Apr. 1996

May 1996

Jun. 1996

Sep. 1996

Sep. 1996

Sep. 1996

Sep. 1996

0ct. 1996

0ct. 1996

0ct. 1996

0ct. 1996

0ct. 1996

0ct. 1996

Nov. 1996

Nov. 1996

Mar. 1997 
38. A Comparative Static Analysis of the Balanced Budget Incidence in the Presence of Sector-Specific Unemployment

39. An Econometric Study of Trade Creation and Trade Diversion in Masahiro Endoh the EEC, LAFTA and CMEA:A Simple Application of the Gravity Model

40. A Dynamic Model of Fiscal Reconstruction

Toshihiro Ihori

\& Jun-ichi Itaya

Apr. 1997

41. The Japanese Way of Solving Financial Institution Failures

0 s amu I to

Apr. 1997

42. The Federal Role in Community Development in the U.S.

Jane Knode 11

Ju 1.1997 Evolution vs, Devolution

43. Rent-Seeking Behavior in the War of Attrition

Jun-ichi It aya

0 ct. 1997

44. サ八リン石油・ガス開発プロジェクトと北海道経済の活性化 第 1 号

Hiroyuki Sano

$0 \mathrm{ct} .1997$

北東アジアー少沙研 究 会

Ma y 1998

45。購買部門の戦略性と企業間連携について

伊藤一

Jun. 1998

46. The Formation of Customs Unions and the Effect on Government Policy Objectives

Masahiro Endoh

47. The Transition of Postwar Asia-Pacific Trade Relations

Masahiro Endoh

Ju 1.1998

48. 地域型ベンチャー支援システムの研究 $\mathrm{I}$ 一道内製造業系ベンチャー企業のケーススタディー

49. Fiscal Reconstruction Policy and Free Riding Behavior of Interest Groups

地域経済社会㳅行研究会

Ju 1.1998

Toshihiro Ihori

\& Jun-ichi Itaya

Aug. 1998

50. Que11en zum Markwesen des 0snabrücker Landes im Niedersächsischen Staatsarchiv 0snabrück (mit Schwerpunkt V Verfassung, Hölting, Siedlung und Konflikten im 17. und 18. Jahrhundert)

Susumu Hirai

Sep. 1998

51. Equity and Continuity with a Continuum of Generations

Tomoichi Shinotsuka

Dec. 1998

52. Public Resources Allocation and Election System

Akihiko Kawaura

Mar. 1999

Discussion Paper Series

treation

0 taru University of Commerce

53. 消費者の偠格プロモーション反応への影響を考慮した広告効果測定結果

54. 地域型ベンチャー支援システムの研究 II - 地域型ベンチャー・インキュベーションの設計 -

55. 州归石油・ガス開発プロジェクトと北海道経済の活性化 第 2 号

56. 石贉洗剤メーカーにおけるマーケテイング・チャ祙行動の変遷

57。長期的取引関係における資源蓄積と展開

58. Exernalities:A Pigovian Tax vs. A Labor Tax

59. A New Dimension of Service Quality:An Empirical Study in Japan

60. Aftermath of the Flint Sit-Down Strike:Grass-Roots Unionism and African-American Workers, 1937-1939

61. Tariff induced dumping in the intermediate-good market

62. Deregulation, Monitoring and 0wnership structure: A Case Study of Japanese Banks

63. 沜少石油・ガス開発プロジェクトと北海道経済の活性化第 3 号

64. A Cooperative and Competitive Organizational Culture, Innovation, and Performance: An Empirical Study of Japanese Sales Departments

65. Foreign Exchange Market Maker's 0ptimal Spread with Heterogeneous Expectations

66. 多ンピングとダンピング防止法の起源文的文脈にお成立

67. The 0rganizational Learning Process: A Review

68. The Weak Core of Simple Games with Ordinal Preferences: Implementation in Nash Equilibrium

69. 業態開発におけるイノベーションと競争ービブレのケースー

70. Budget Distribution Problem

71. 小売バイヤー組織の機能と顧客対応

72. The Effect of Intra-0rganizational Competition on Knowledge Creation: Case Study of a Japanese Financial Company

73. 涉ン石油・ガス開発プロジェクトと北海道経済の活性化 第 4 号

74. The Weak Core of Simple Games with Ordinal Preferences: Implementation in Nash Equilibrium

75. 環境保全型河川計画と景観構築に係る計画技術の研究

76. Additivity, Bounds, and Continuity in Budget Distribution Problem
奥 瀬 喜 之

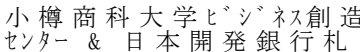
セン多一 \&

北東アジアー州リン研 究 会 高宮城朝則

近藤公彦＆坂川裕司

Ko Sumino

Makoto Matsuo

\& Carolus Praet

\& Yoshiyuki Okuse

Satoshi Takata

Chisato Shibayama

Akihiko Kawaura

北東アジアー州沙研 究会

Makoto Matsuo

Ryosuke Wada

柴山千里

Makoto Matsuo

Tomoichi Shinotsuk

\& Koji Takamiya

近藤公彦

Tomoichi Shinotsuka

伊藤

Makoto Matsuo

北東アジアー州リン研 究 会

Tomoichi Shinotsuka \& Koji Takamiya

地域環境問題研究会

Tomoichi Shinotsuka
Jun. 1999

Ju 1.1999

May 1999

Dec. 1999

Dec. 1999

Dec. 1999

Dec. 1999

Mar. 2000

Apr. 2000

Apr. 2000

Apr. 2000

May 2000

Jun. 2000

$0 \mathrm{ct.} 2000$

Dec. 2000

Jan. 2001

Jan. 2001

Feb. 2001

Ma y 2001

May 2001

Mar. 2001

$0 \mathrm{ct} .2001$

$0 \mathrm{ct.} 2001$

Dec. 2001 
77. Monetary Policy in Bhutan: Implications of Indian Rupee Circulation

78. Optimal Multiobject Auctions with Correlated Types

79. サハリン石油・ガス開 発プロジェクトと北海道経済の活性化 第 5 号

80. The Case Study of Retail Buying Organization in Japanese Context

81. 宿泊業のサービスのサービス構成要素に関する重要度調査法に 関しての一考察北海道への台湾人観光客の事例を中心に

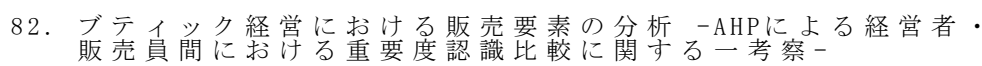

83. 温泉地に対するイメージギャップに関する調査

84. Literature Review on Retail Buyer from Research on Industrial Purchasing

85. The Comparison Study on Retail Buyer Behaviour between UK, Australia and Japan

86. 社会科学研究の基礎一大学院生のための研究法 -

87. マー方テ氐弟行為からみた少壱業による需要领造

88. Interdependent Utility Functions in an Intergenerational Context

89. Internal and External Views of the Corporate Reputation in the Japanese Hotel Industry

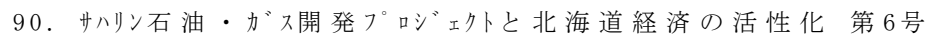
91. 小売購買行手動研究に関する゙展望行動研究に向けてー

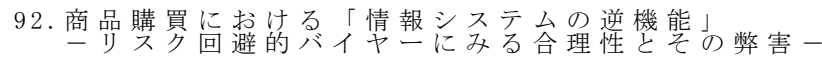

93. An Experiment of Round-Robin Tournament by Excel's Macro -Using 160 Students' Data from Cournot Duopoly Game-

94. Earnings Management through Deferred Tax Aseets In Case of Banking Company-

97. Competition between Matching Markets

98. 0n the role of asymetric information in the aggregate matching function

99. A note on 0ptimal Taxation in the Presence of Externalities

100. A Note on Jones' Model of Growth

101 . 整数ナ学プサック問題が多項式時間で解ける特殊な場合を

102. I T 技術者の熟達化と経験学習

103. Product De-1isting by Retail Buyers: Relational Antecedents and Consequences

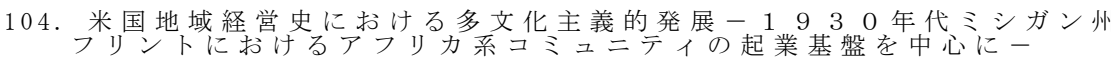

105. 環境便益を反映させた環境指標の開発 Deve1oping

an environmental indicator including environmental benefits

106. A Critical Investigation of Long-run Properties of Endogenous Growth Models

107. What is National Income in Jones' Model of Growth? :An Expository Annotation

108. A Further Analysis of the Consumer Behavior in Jones' R\&D-Based Mode1 of Economic Growth

109. 看護師の経験学習プロセス

110. Comments on knapsack problems with a penalty

111. 看護師の経験学習に関する記述的分析

112. 頂点被覆へのリスト減少法の解析に関する一考察

113. 小中学校における校長の経営観一探索的分析 114. 䦓屋の経営活铜査：戦後復興期大阪における自転車部品製造業者・

115.Partitionのある風景

116. Multiproduct Firms and Dumping

117. モスクワの低層住宅団地開発一2つのケースー

118. 整数ナップサックの周期性について

Akihiko Kawaura

Dec. 2001

Tomoichi Shinotsuka

Feb. 2002

\& Simon Wilkie

北東アジアーサハリン研究会 Hajime Itoh

Mar. 2002 Mar. 2002

稲葉由之\&沈潔如 \& 伊藤一 Feb. 2003

伊藤一＆橋詰敦 樹

Mar. 2003

伊 藤

Mar. 2003

Hajime Itoh

Hajime Itoh

ダン・レメ二イ他著

抄訳稲葉由之\&奥瀬善之

\&近藤公战期 \&井健

坂川裕司

May 2002

Tomoichi Shinotsuka

May 2002

Hajime Itoh

Feb. 2003

北東アジアー州リン研 究 会

Mar. 2003

坂川裕司

May 2003

坂川裕司

Sep. 2003

Masaru Uzawa

Apr. 2004

Hiroshi Onuma

Jun. 2004

Koji Yokota

May 2005

Koji Yokota

Tomoichi Shinotsuka

\& Ko Sumino

Mutsuhiro Kato

飯田浩志

松尾睦

Gary Davies

\& Hajime Itoh

高田聡

山本充

Mutsuhiro Kato

Mutsuhiro Kato

Mutsuhiro Kato

Apr. 2006

Feb. 2005

Mar. 2005

Ju 1.2005

Sep. 2005

Dec. 2005

May 2006

Apr. 2006

May 2006

Jun. 2006

Aug. 2006

\&松尾岡睦子 \& 歖田真奈美

\& 丸山知子 \& 瞽本萘緒

Feb. 2007

Iida Hiroshi

Mar. 2007

松尾岡䝰子 \& 程田真奈美
\& 緒

飯田浩志

Dec. 2007

松尾睦

Dec. 2007

田中幹大

Apr. 2008

飯田浩志

Jun. 2008

Chisato Shibayama

\& Yasunori Ishii

Ju 1.2008

小田福男

Mar. 2009

飯田浩志

Mar. 2009 
119. Discussion paper series no. 118 への補遺

120 . 環境フ洅考察バック効果を考慮したSandmoモデルによる二重配当

121. 部分線形モデルの差分推定量の漸近理論

122. モデル平均理論の新展開

123. Production Theory with Convex Labor Friction: Foundation of an 0ptimal Non-market-clearing Economy

124.19世紀ドイツの農村ゲマインデ制と政治参加資格

125. 環境経営と企業業績に関する実証研究（再検討：2003-2008）

126.「北海道ブランド」の仕入れに関する研究

127. Generalized Cp Model Averaging for Heteroskedastic models

128. How to solve the collapsing subset-sum problem revisited

129. 顧客関係のマネジメントの系譜

130. An Application of Forecast Combination Methods to Default Risk Prediction

131. An effect of consumer's earlier decision to purchase a discount ticket

132. On the Behavior of money flows on the real side and the financial side in Hokkaido prefecture

133. 星野リゾートー 顧客志向の組織マネジメントー 134. (ケース) 札幌ビズカフェー地域企業家ネットワークにおける

135.二重配当効果の最適課税ルールにしたがった再評価

136. $18 \cdot 19$ 世紀前半北海沿岸農村社会の地域役職者 : Landschaft Eiderstedt

137. Tax Collecting Efforts and Local Allocation Tax Grants in Japan: The Effect of Administrative Reform Incentive Assessment on Local Tax Collection Rate

138. The bargaining family with strategic interaction

139. Generalized Cp Model Averaging for Heteroskedastic Models (Revised Version)

140. Exclusion of agents, virtual surplus and a transversality condition in adverse selection

141. Implementability by a canonical indirect mechanism of an optimal two-dimensional direct mechanism

142. 18・19世紀前半北西ドイツ北海沿岸地方の領邦官吏と自治組織役職者 : Landschaft S?derdithmarschen

143. CRMにおける顧客関係のマネジメント

144. 企業家ネットワーキングによる地域企業のビの゙ネ事例分析システム・イノ

145. Observable Actions

146. Dumping in Transition Economies and the Effects of Anti-Dumping Policy

147. Time Discount and Convex Hiring Cost

148. Two-dimensional Mechanism Design and Implementability by an Indirect Mechanism

149. 北海道経済と開発のプロセス

150。道内における地域経済の現状について

151. モンゴルにおける資本主義転換後の地域間経済格差に関するパネル

152.モンゴルにおける食肉価格の動向に関するパネルデータ分析

153. 付加偠值率の動向炎地方息治体による政策効果の関係について

154. CRMにおける組織能力

155. 19世紀北西ドイツの農村ゲマインデ制の変革---自治参加資格と 家屋・土地保有要件-

156. 北海道における産業クラスターに関する文献資料目録

157.下ヨタ自動車北海道のマネジメント

158. Mechanism design to the budget constrained buyer: a canonical mechanism approach

159. First Price Package Auction with Many Traders
加賀田和弘

Apr. 2010

沈潔如

Apr. 2010

Qingfeng Liu

$0 \mathrm{ct.} 2010$

Hiroshi Iida

Jan. 2011

近藤公彦

Feb. 2011

Qingfeng Liu

Feb. 2011

Ryosuke Ishii

\& Kuninori Nakagawa

Feb. 2011

Toshiaki Kanzaki

Mar. 2011

乙政佐吉

Mar. 2011

加藤敬太

Mar. 2011

角野 浩

Mar. 2011

平井進

Mar. 2011

Mitsunari Ishida

Mar. 2011

Atsue Mizushima

\& Koichi Futagami

Mar. 2011

Qingfeng Liu

Apr. 2011

Naoki Kojima

May 2011

Naoki Kojima

Jun. 2011

Jun. 2011

近藤公彦

Aug. 2011

加藤 敬 太

$0 \mathrm{ct} .2011$

Ryosuke Ishii

Nov. 2012

Chisato Shibayama

Mar. 2012

Koji Yokota

May 2012

Naoki Kojima

Jun. 2012

神㟝稔章

Dec. 2012

渡久地朝央

\& Baljinnyam Maitsetseg Dec. 2012

渡久地朝央

\& Baljinnyam Maitsetseg Dec. 2012

Ba 1 jinnyam Maitsetseg Dec. 2012

渡久地朝央

Dec. 2012

近藤公彦

Feb. 2013

平井進

Feb. 2013

加藤 敬 太

Mar. 2013

乙 政 佐 吉

Mar. 2013

Naoki Kojima

May 2013

Yasuhiro Shirata

Jun. 2013 
Discussion Paper Series Department of Economics, Otaru University of Commerce No. 1-16

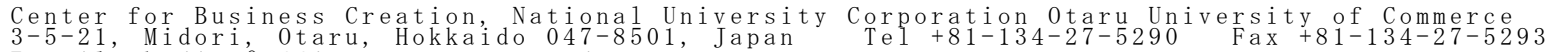
E-mail:cbcjimu@office.otaru-uc.ac.jp

国立大学法人小樽商科大学ビジネス創造センター 个海道小樽市緑 3 丁目 5 番 2 